UNNES Journal of Literature, Linguistics and Cultural Studies

\title{
Oscar Wilde's Writing Style in The Happy Prince in View of Transitivity Analysis
}

Monica Intan Sari ${ }^{\bowtie}$, Henrikus Joko Yulianto

English Department, Languages and Arts Faculty, Universitas Negeri Semarang, Indonesia

\begin{tabular}{|c|c|}
\hline Article Info & Abstract \\
\hline $\begin{array}{l}\text { Article History: } \\
\text { Received } 19 \text { February } 2019 \\
\text { Approved } 25 \text { July } 2019 \\
\text { Published } 29 \text { July } 2019\end{array}$ & $\begin{array}{l}\text { This study was aimed to discover the types of processes used and how they influence the } \\
\text { author's writing style in Oscar Wilde's short story entitled "The Happy Prince". The } \\
\text { methodology used in this study was descriptive-qualitative so the analysis was presented } \\
\text { in the form of words, phrases, sentences, and utterances. The study focused on discourse } \\
\text { analysis employing ideational function approach, which analyzed the short story from } \\
\text { the point of view of linguistics especially Transitivity, a theory developed by M. A. K. } \\
\text { Halliday. As a result, there were seven types of processes found in the story namely } \\
\text { material, mental, behavioral, verbal, relational, existential, and meteorological. The } \\
\text { results of the study showed that material process was the most frequently used process } \\
\text { (37\%) conducted by the author. Yet, the six others were each employed for about } 1 \% \text { - } \\
25 \% \text {. This indicated that the use of the type of process influenced the writing style of the } \\
\text { author in constructing the story where the different process emphasized different } \\
\text { portrayal. However, it was also supported by the author's previous career and } \\
\text { achievement as a journalist, editor, and critic. Ultimately, the researcher found that Oscar } \\
\text { Wilde's writing style included the vivid descriptions, aesthetic appearance, } \\
\text { conversational style, repetitive pattern, simple and clear language. }\end{array}$ \\
\hline
\end{tabular}

(C) 2019 Universitas Negeri Semarang

\footnotetext{
Corresponding Author

E-mail: monicaintans@gmail.com
}

ISSN : 22526323 


\section{INTRODUCTION}

Language basically functions as a medium of communication in which people convey any kinds of ideas to get each other's understanding. In conveying the ideas, either in speaking or writing people must produce a text. Since text refers to any instances of language, in any medium, that makes sense to someone who knows the language (Halliday and Hasan, 1976). In line with this, we need a theory of grammar to help us understand how texts work. There is Functional Grammar which views language as a resource for making meaning (Halliday's Introduction to Functional Grammar 4th Edition, p.22).

Gerot and Wignell stated that functional grammar is not only concerned with the structures but also with how those structures construct meaning. It attempts to describe language in actual use and focuses on texts and their contexts. There are three broad aspects of functional grammar which are called metafunctions namely ideational function, interpersonal function, and textual function (Halliday, 1994). In this research, the researcher focused on ideational metafunction which is concerned with the phenomena - what or do what, about goings-on - whose relationship is divided into three elements: process, participant, and circumstance. There are different kinds of goings on, which will involve different kinds of participants in various circumstances. The grammatical system which concerned with this figure is Transitivity.

Some previous researches have been conducted related to transitivity analysis, such as Pattama J.P. (2008), Jesu's Moya Guijarro (2007), Wahyu Dwi (2010), Bonifacio T. Cunanan (2011), Hanh Thu Nguyen (2012), Zijiao Song (2013), Asad Mehmood et al (2014), Laya Heidari Darani (2014), Humphrey Kapau (2015), Niyati Wulandari (2016), Monika Kavalir (2016), Arina Isti'anah (2018). There are only several kinds of researches conducted on Oscar Wilde's work with the relation between the processes used in the short story and his writing style since the researchers were mostly focused on the others perspective to analyze his works such as Feminist, Marxist, Psychoanalytic, and Deconstruction. Therefore, I conduct this research to reveal how the field of the situation is being constructed in the story through the identification of the types of existing processes, what processes mostly presented, and how the processes influence the writing style of the author by analyzing Oscar Wilde's "The Happy Prince", which was published in 1888 , by using the system of Transitivity by Halliday.

\section{METHODS}

This research used qualitative research design. It helps the readers understand what the author tries to tell through his work from linguistic point of view. The data, both the processes and the findings in the research are described in the form of words, phrases, sentences, and utterances, not numbers or graphics. As Miles and Huberman (1994) stated that the data obtained from qualitative research are usually in the form of words rather than numbers and these words are based on observation, interviews or documents.

Furthermore, in conducting the research, the researcher used Ideational Metafunction approach which focus on the process types of the related short story. An analysis of a text from the perspective of the ideational function involves inquiring into the choices in the grammatical system of transitivity; that is, process types, participant types, circumstance types, combined with an analysis of the resources through which clauses are combined (Halliday and Matthiessen, 2004).

\section{RESULTS AND DISCUSSIONS}

\section{Types of Processes Found in Oscar Wilde's The Happy Prince \\ Material Process}

Clauses with a material process obligatory have a doing as the process and a doer as the participant (Gerot and Wignell, 1995:55). Material process is a process of doing something 
or an action. The participants involved in this process are actor and goal.

'High above the city, on a tall column, stood the statue of the Happy Prince'

\begin{tabular}{lll}
\hline $\begin{array}{l}\text { High above the } \\
\text { city, on a tall }\end{array}$ & Stood & $\begin{array}{l}\text { the statue } \\
\text { of the } \\
\text { column }\end{array}$ \\
& & $\begin{array}{l}\text { Happy } \\
\text { Prince }\end{array}$ \\
\hline Circumtance: place & Material & Actor \\
\hline
\end{tabular}

The entity who or which does something is the participant. In this case, 'the statue of the Happy Prince' is categorized as the actor since it is the one who does something as the (material) process that is 'stood'. In addition, the clause above also has circumstance involved, 'high above the city, on a tall column', which explains where the happening takes place.

It is not the position of participants that affect the identification but the process. When the process turns to be a passive or active, it will change the participant's categorization as well.

'but the Reed shook her head'

\begin{tabular}{lll}
\hline the Reed & shook & her head \\
\hline Actor & Material & Goal \\
\hline & & Data no.54
\end{tabular}

The data number 54 above is the example of an active clause which represents the material process with actor and goal. The first noun phrase 'the Reed' as the actor, the verb phrase 'shook' as the process, and the second noun phrase in the last position as the goal of the clause. It will be 'her head was shaken by the Reed' in passive voice, but still, the analysis will be 'her head' as the goal, 'was shaken' as the process, and 'the Reed' as the actor.

\section{Mental Process}

Mental process refers to the process of sensing. A clause with mental process is concerned with people's experience of the world of their own consciousness. The process has senser as the participant involved that is commonly human. Grammatically, the participant involved in mental process is presented in the terms of 'he' or 'she', not 'it'. But, uncommonly, it can be a product of human consciousness or can also be represented by parts of a person.

Furthermore, mental process is divided into four types of sensing namely affection, cognition, perception, and desideration. Each type of sensing represents different process of sensing; the affection refers to feeling, the cognition refers to thinking, the perception refers to perceiving, and the desideration refers to wanting.

"I don't think I like boys,"

\begin{tabular}{lll}
\hline I & don't think & \\
\cline { 1 - 2 } Senser & Mental: cognition & \\
\cline { 1 - 1 } & \multicolumn{2}{l}{ boys } \\
\hline I & like & Phenomenon \\
\hline & Mental: affection & Data no.138
\end{tabular}

The example, data number 138 , consists of two different types of mental process. Those are 'think' that belongs to cognitive verbs and 'like' that belongs to affective verb.

'You have never seen one'

\begin{tabular}{lll}
\hline You & have never seen & One \\
\hline Senser & $\begin{array}{l}\text { Mental: } \\
\text { perception }\end{array}$ & Phenomenon \\
\hline
\end{tabular}

Data no. 21

In the data number 21 , the first participant involved is 'you' as the senser who does the process of sensing 'seen'. The 'have never seen' expresses the perceptive mental process since 'seen' can be sensed sensorily by using part of one's body namely eyes. The last part of the clause above, 'one', is categorized as phenomenon, the second participant of the mental clause. The word 'one' here refers to an angel in "The Happy Prince" story that becomes the object of consciousness which is done by 'you' (the children) as the senser.

"I hope the town has made preparations." 
Rainbow: Journal of Literature, Linguistics and Cultural Studies, Vol. 8 (1) (2019)

\begin{tabular}{|c|c|c|c|c|}
\hline I & hope & $\begin{array}{l}\text { the } \\
\text { town }\end{array}$ & $\begin{array}{l}\text { has } \\
\text { made }\end{array}$ & $\begin{array}{l}\text { preparation } \\
\text { s }\end{array}$ \\
\hline & & $\begin{array}{l}\frac{1}{2} \\
\frac{2}{0} \\
9\end{array}$ & 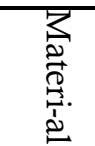 & $\begin{array}{l}\text { Q } \\
\stackrel{0}{0}\end{array}$ \\
\hline
\end{tabular}

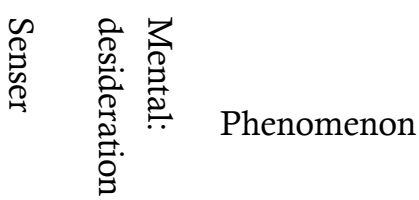

Data no.62

While in the data number 62 , the mental process expresses the process of expecting something that is 'hope', which belongs to desiderative verb. The word 'hope' reveals the desire of someone for something. In the data above, the phenomenon is presented in the form of an act 'the town has made preparations' that can be analyzed again as the material process.

Therefore, the words 'admired', 'seen', 'think', 'like', and 'hope' in those data are all mental processes, but they refer to different types of sensing. 'Admired' and 'like' express the emotive/affective verbs, 'seen' expresses perceptive verb, 'think' expresses cognitive verb, and 'hope' expresses desiderative verb.

\section{Behavioral Process}

Behavioral process is located at the boundary between material process and mental process so that they are partly like material and partly like mental. The participant is labeled as behaver that is similar to senser but the process is grammatically like the process of doing in material process. Usually, the pattern of behavioral process is "the participant + the process only" as can be seen in the data number 56 below:

\begin{tabular}{ll}
\hline he & cried \\
\hline behaver & Behavioral \\
\hline
\end{tabular}

Data no. 56

Yet, behavioral process, in another case, has two types of participants namely behaver and range.

'and he sank into a delicious slumber'

\begin{tabular}{llll}
\hline he & sank & $\begin{array}{l}\text { into a delicious } \\
\text { slumber }\end{array}$ \\
\hline Behaver & Behavioral & Range \\
\hline \multicolumn{3}{l}{ Data no.173 }
\end{tabular}

Based on the example above, the first participant behaver is 'he' who 'sank into a delicious slumber' as the behaving in this behavioral clause. The word 'sank' is followed by 'into a delicious slumber', which suggests a good sleep. The second participant is called range that names the behavior enacted.

\section{Verbal Process}

Verbal process is a process of saying. 'Saying', in a broad sense, covers any kind of symbolic exchange of meaning. It is commonly used for reporting and quoting. Sayer is the central participant involved, which represents the speaker or the subject of the clause. There are three other participant functions in addition to sayer, namely receiver, verbiage, and target.

"only not quite so useful," he added,

\begin{tabular}{llll}
\hline $\begin{array}{l}\text { "only not quite } \\
\text { useful," }\end{array}$ & so & he & added \\
\hline Verbiage & & Sayer & Verbal \\
\hline & & & Data no.8
\end{tabular}

The clause above is divided into three phrases; there are 'only not quite so useful' as the verbiage; 'he' as the sayer, and 'added' as the verbal process. The only entity that says something is 'he' so that it turns to the speaker in the clause. 'Added' here is categorized as the verbal process since it represents the process of saying that adds some information to other utterance spoken by anyone else before.

The meaning of the clause can be revealed in a further analysis which shows that functionally, it functions as the secondary clause in a complex clause, being either directly quoted as in "(it's) only not quite so useful" he added or indirect reported as in he added (that) it's only quite so useful.

He told him of the red ibises,

He told him of the red ibises




\begin{tabular}{lrrr}
\hline sayer & verbal & receiver & Verbiage \\
\hline & & Data no.301
\end{tabular}

The clause above can be divided into four parts; 'he', the first participant, as the one who says something to someone else is construed as sayer; 'told' as the process of saying something to someone else is construed as verbal process; 'him', the second participant, as the one who receives something from someone else is construed as receiver; and the last participant, 'the red ibises', as the thing which is told by someone to other is labeled as verbiage. In addition to those three participants, there is another type of participant in verbal process namely target. But, unfortunately, there is no clause with target existing that is found in the whole story of "The Happy Prince".

The process of saying in verbal clause is not always represented by the word 'say'. Beside 'say', from the examples that have been discussed, we also have 'added' and 'told' as the verbal process.

\section{Relational Process}

Relational process intends to characterize and to identify something. It is the process of being and having. The participant involved in a relational clause is not only things but also acts and facts. They are construed as 'being': something is said to 'be' something else. For example:

'that she is a coquette'

\begin{tabular}{lll}
\hline she & is & a coquette \\
\hline Carrier & Attributive & Attribute \\
\hline
\end{tabular}

Data no.47

In relational clause, the English system operates with three types of relation namely intensive, possessive, and circumstantial, and they come in two modes of being namely attributive and identifying. Data number 47 above shows the attributive intensive process which is represented by to be 'is'. In this attributive process, the participants are divided into two, namely carrier and attribute, which each is represented by 'she' and 'a coquette'.
The second type of attributive process is possessive, which reveals a possession. And the last type is circumstantial, which reveals a process with detailed circumstance information. The examples are as follows:

'he had two bright sapphires'

\begin{tabular}{llc}
\hline $\mathrm{He}$ & $\mathrm{Had}$ & $\begin{array}{l}\text { two bright } \\
\text { sapphires }\end{array}$ \\
\hline Carrier & $\begin{array}{l}\text { Attributive: } \\
\text { possessive }\end{array}$ & Attribute \\
\hline
\end{tabular}

Data no.3

This clause has 'had' as the process of possession namely attributive: possessive. It reveals that something/somebody owns something/somebody else. 'He'is the subject of the clause namely carrier, somebody who owns something as the attributes; 'two bright sapphires'. 'and it lasted all through the summer'

\begin{tabular}{lll}
\hline it & lasted & $\begin{array}{l}\text { all through the } \\
\text { summer }\end{array}$ \\
\hline Carrier & $\begin{array}{l}\text { Attributive: } \\
\text { circumstantial }\end{array}$ & Attribute \\
\hline
\end{tabular}

Data no.39

Meanwhile, the data number 39 is a relational clause with attributive circumstantial process. The clauses have 'it' as the carrier, the first participant of relational process. 'Lasted' is as the circumstantial process. And, as the second participant, attribute, it has 'all through the summer'.

Another mode of relational process is identifying, which aims to reveal the identity of something. The participants involved in this process include token and value: the identified is token, and the identifier is value.

'I am the Happy Prince.'

\begin{tabular}{lll}
\hline I & am & the Happy Prince \\
\hline Token & Identifying & Value \\
\hline
\end{tabular}

Data no. 89

The first participant of the identifying relational clauses above is ' $\mathrm{I}$ ', the identified thing namely token. Whereas, the second participant 
namely value which expresses the identifier of the clauses are 'the Happy Prince'. To link the token and the value in the relational clause above, it has each 'am' as the identifying process.

\section{Existential Process}

Existential process reveals that something exists or happens (Halliday and Matthiessen, 2004:256). It functions to introduce something. The existential clause is usually featured by the word 'there', but it is neither a participant nor circumstance. The only participant involved is called existent, something that is being said to exist.

'there is someone in the world who is quite happy'

\begin{tabular}{llll}
\hline (There) is & someone & in the world & $\begin{array}{l}\text { who is } \\
\text { quite } \\
\text { happy }\end{array}$ \\
\hline Existential & Existent & $\begin{array}{l}\text { Circumstance: } \\
\text { place }\end{array}$ & $\begin{array}{l}\text { Mental: } \\
\text { affective }\end{array}$ \\
\hline & & Data no.15
\end{tabular}

In the clause above, we can directly see the word 'there' as the starter. The process itself is expressed by 'is' as the process of existing. And, something that is being said in the clause is 'someone', which functions as the existent.

"there stands a little match-girl.

\begin{tabular}{|c|c|}
\hline there stands & a little match-girl \\
\hline Existential & Existent \\
\hline
\end{tabular}

From the data number 270 , it shows that the existential process can also reveal that there is something happening. The happening as the existential is expressed by verb 'stands' which is followed by the existent 'a little match-girl'.

\section{Meteorological Process}

Meteorological process is the process concerned with the weather. It is on the borderline between existential process and material process. What makes the process different is that it has no participant. So that, the meteorological clause can be analyzed as consisting of a single element, namely process. 'it is raining'

\begin{tabular}{ll}
\hline it $\quad$ is raining \\
\hline Meteorological \\
\hline
\end{tabular}

Data no.74

The meteorological process in data number 74 has only one participant, meteorological 'raining', while the word 'it' has no representational function, but is required due to the need for a subject in English grammatical system.

Based on those seven types of processes found in Oscar Wilde's "The Happy Prince", the most frequently used process is material process. It indicates that this is a narrative story which concerned with actions and events. Verbs representing the material processes are: stood, came out, had gone away, had met, was playing, had stopped, made a low bow, is always flirting, blew, shook, put, and etc. These verbs establish the dynamic interaction of the main characters with the outer world. And these actions are sometimes repeated throughout the whole text. The percentage result of each seven process used in Oscar Wilde's "The Happy Prince" is as follows:

Table 4.1 Table of Data Tabulation

\begin{tabular}{lll}
\hline Types of process & Frequency & Percentage \\
\hline Material & 201 & $37.02 \%$ \\
Mental & 59 & $10.87 \%$ \\
Behavioral & 58 & $10.68 \%$ \\
Verbal & 78 & $14.36 \%$ \\
Relational: & & \\
Attributive & 109 & $20.07 \%$ \\
Identifying & 21 & $3.87 \%$ \\
Existential & 12 & $2.21 \%$ \\
Meteorological & 5 & $0.92 \%$ \\
\hline Total & 543 & $100.00 \%$ \\
\hline
\end{tabular}




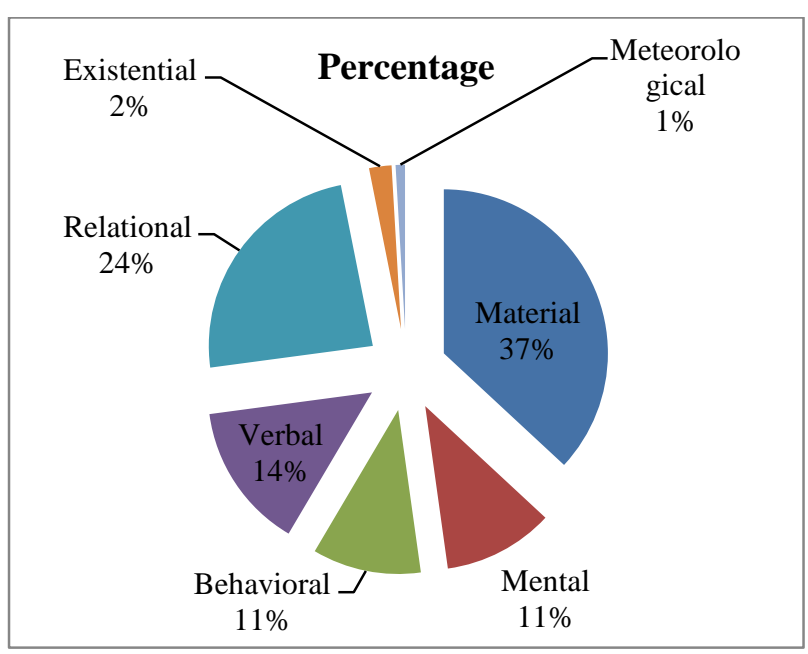

Figure The percentage of Types of Process in The Happy Prince

As stated by the figure 4.1 , the author tends to use material process type more than the other process types (37\%). The researcher found that Wilde, in writing the story "The Happy Prince", used the material process frequently with the frequency of 201 times of total 543 processes. The material processes are marked by the existence of action verbs. Wilde, in writing the story, tried to sketch The Happy Prince through his actions. Indirectly, through The Swallow's help, The Happy Prince did many actions to mend the situation. Based upon the number of material process found in the story, The Happy Prince and The Swallow as the main characters have dominant role as an Actor. They became the Actor and their actions dominantly affect the others.

Therefore, the style that an author uses influences how the readers interpret the facts that are presented. By conducting the transitivity analysis, we can see that wording and phrasing can tell us about the field of situation including the emotions in the scene, the setting, and the characters.

\section{Oscar Wilde's Writing Style}

\section{Types of Processes Influence}

An author's writing style is usually a reflection of his or her personality, conscience, and way of approaching the readers. In "The
Happy Prince", Wilde portrays the characters as if they are real and depicts the environment as if it really exists around us. Wilde needs at least one paragraph with some kinds of processes in portraying the character (in this case The Happy Prince as the main character).

High above the city, on a tall column,
stood the statue of the Happy
Prince.He was gilded all over with thin
leaves of fine gold; for eyes he had two
bright sapphires, and a large red ruby
glowed on his sword-hilt. (The Happy
Prince, 1888)

Relational process is the most frequently used process by an author to portray a character. Yet, in the excerpt above, Oscar Wilde not only employs relational process but also material process as we can see the analysis below:

High above the city, on a tall column, stood the statue of the Happy Prince.

\begin{tabular}{lll}
\hline $\begin{array}{l}\text { High above the city, } \\
\text { on a tall column }\end{array}$ & $\begin{array}{l}\text { the statue of } \\
\text { the Happy } \\
\text { Prince } \\
\text { Circ: place }\end{array}$ & Material \\
\hline
\end{tabular}

Data no.1

He was gilded all over with thin leaves of fine gold;

\begin{tabular}{lll}
\hline He & was gilded all over & $\begin{array}{l}\text { (with) thin } \\
\text { leaves of fine } \\
\text { gold }\end{array}$ \\
\hline Carrier & $\begin{array}{l}\text { Relational: } \\
\text { Attributive (intensive) }\end{array}$ & Attribute \\
\hline & & Data no.2
\end{tabular}

The choice of words and the process used by the author are interrelated. The words chosen represent how wonderful the statue is, and the processes used represent the way Wilde points out the wonderfulness of the main character. The atmosphere of the character was built by the words while the identity and the characterization were built by the processes.

To support the depiction of the character and characterization, Wilde also employed 
mental process through other character's feeling, thought, perception, and desire as we can see at the examples below:

'I did not know what tears were,'

\begin{tabular}{lll}
\hline I & did not know & what tears were \\
\hline Senser & $\begin{array}{l}\text { Mental: } \\
\text { cognition }\end{array}$ & Phenomenon \\
& & \\
\hline
\end{tabular}

Data no.98

' $\mathrm{I}$ ' in the data number 98 refers to The Happy Prince. He told the Swallow about his past, his previous life, in the palace of Sans Souci when he was alive. The clause indicates that his previous life was good since he did not even know what tears were.

'that I can see all the ugliness and all the misery of my city,'

\begin{tabular}{lll}
\hline I & can see & $\begin{array}{l}\text { all the ugliness and } \\
\text { all the misery of my } \\
\text { city }\end{array}$ \\
Senser & $\begin{array}{l}\text { Mental: } \\
\text { perception }\end{array}$ & Phenomenon \\
\hline
\end{tabular}

The clause above supports its previous idea of the story that describes the statue of The Happy Prince's location in the town. But not only that, the mental process also shows that the statue was built at that place for a reason. He, The Happy Prince who never knows what sorrow is, becomes someone who can see all the negativity of the town he lived in. He also realizes that sadness is not allowed to afflict the palace of the Prince. Now he knows how the real life is, in which there will always be a powerful and powerless entity. When he was in the palace, he did not even know what tear was, and one thing he knew all that time was happiness. In contrast, nowadays, in every day and night as a statue of the Happy Prince, he has to see the misery around him. It shows that The Happy Prince is a sensitive person for he felt sorry about knowing nothing of what really happened to his surroundings.

Meanwhile, to depict the environment he emphasizes the diction of the setting as can be seen at the beginning of the story "High above the city, on a tall column, stood the statue of the Happy Prince". The analysis of data number 1 shows the use of circumstance of location to describe the environment where the story takes place. In constructing the story, Wilde, 173 times used the circumstance of location either temporal (time) or spatial (place). For example: 'and sat a long time on top of the church steeple'

\begin{tabular}{lll}
\hline and sat & a long time & $\begin{array}{l}\text { on top of the } \\
\text { church steeple }\end{array}$ \\
\hline Behavioral & Circ.: & Circ.: \\
& location(time) & location(place) \\
\hline
\end{tabular}

The datum shows that Wilde considers the use of circumstance of location as an important thing to construct a story so that this can lead the readers into the flow of the story as well. The author used the circumstance of location not only for describing the environment or the setting of the story but also for completing the depiction of the character. In this case, the character is the Swallow who was pleased when he stopped for a long time on his way to Egypt in a place (top of the church steeple) where other birds watched and talked about him.

Ocsar Wilde constructed the story of "The Happy Prince" with dialogues and narrations, most of them are in the form of dialogue. A dialogue usually involves verbal process. Based on the analysis, $14.39 \%$ of the story is constructed by verbal process with the frequency of 78 times found from 543 processes existed. They are identified by verb like "say", "tell", "shout" etc.

The Prince never says anything to other people till he met the Swallow. From 78 verbal processes found in the story, there are only 20 verbal processes where The Prince is the sayer and The Swallow as the addressee. It represents that their friendship is truly existent as The Swallow is the one whom The Prince trusts to talk to. The rest sayers of the processes are The Swallow and some other characters like The Town Councilors, The Professor, and the society around the town in which the statue of the prince is the topic being talked by them (see table 4.2). It indicates that 
verbal process also becomes one of the ways Oscar Wilde portrays the character in this story.

Table 4.2 Sayer of Verbal Process

\begin{tabular}{lll}
\hline Sayer & Frequency & Percentage \\
\hline The Happy Prince & 20 & $25.6 \%$ \\
The Swallow & 28 & $35.9 \%$ \\
Others & 30 & $38.5 \%$ \\
Total & 78 & $100.0 \%$ \\
\hline
\end{tabular}

The repetitive pattern is also used by the author during the story especially in the dialogue, so that the readers can see the relationship among the characters. It happened to the Prince and the Swallow as follows:

"Swallow, Swallow, little Swallow," said the Prince,

\begin{tabular}{lll}
\hline $\begin{array}{l}\text { Swallow, Swallow, little } \\
\text { Swallow }\end{array}$ & said & the Prince \\
\hline & Verbal & Sayer \\
\hline & Data no.134
\end{tabular}

"will you not stay with me for one night,

\begin{tabular}{llll}
.." & & & \\
\hline (will) & not stay & with me & $\begin{array}{l}\text { for one } \\
\text { night, }\end{array}$ \\
you & & & Circ.:locat \\
\hline Behav & Behavio & Circ.: & accompani \\
er & ral & ion \\
& & ment & \\
\hline
\end{tabular}

Data no. 135

"...I will stay with you..."

\begin{tabular}{lll}
\hline I & will stay & with you \\
\hline behaver & behavioral & Circ.: \\
& & accompaniment \\
\hline
\end{tabular}

The first clause is repeated six times in the story; data number $134,198,209,233,255$, and 284 (see appendix 2). The second clause is repeated three times in the story; data number 135,199 , and 256 (see appendix 2). And, the third clause is repeated four times in the story; data number 148, 281, 294, and 297 (see appendix 2).

Those clauses happened in the dialogue between the Prince and the Swallow. Time after time, The Prince asked The Swallow to stay with him in the town. At the very first time, The Prince asked The Swallow to stay and become his messenger at that night so that The Swallow undertook it. Until every night after, The Prince asked the Swallow to help the poor society around the town. Lastly, The Swallow stayed with The Prince until his death coming because he felt he could not bear to leave The Prince in a very sad situation.

Based on the examples above, we can also see that behavioral process was conducted to emphasize what was really wanted by both the Prince and the Swallow so that the readers can feel the same as theirs. Another behavioral process conducted by the author is also shown in the following line:

'he gazed at the wonderful statue'

\begin{tabular}{lll}
\hline $\mathrm{He}$ & gazed & $\begin{array}{l}\text { at the wonderful } \\
\text { statue }\end{array}$ \\
\hline Behaver & Behavioral & Circ: location \\
\hline & & \multicolumn{1}{c}{ Data no.17 }
\end{tabular}

' $\mathrm{He}$ ' in this case is one of the citizens who is amazed with the beauty of the statue which seemed a quite happy not like him. He compared his life to the Happy Prince. It indicates that in people's mind the Happy Prince is a figure who is always happy and coveted by everyone. This assumption is supported by the example as follow:

"The Happy Prince never dreams of crying for anything."

\begin{tabular}{lll}
\hline $\begin{array}{l}\text { The Happy } \\
\text { Prince }\end{array}$ & never dreams & $\begin{array}{l}\text { of crying for } \\
\text { anything }\end{array}$ \\
\hline Behaver & Behavioral & Range \\
\hline \multicolumn{2}{c}{ Data no.13 }
\end{tabular}

Wilde used those behavioral clauses to lead the readers' assumption towards the characters in the story so that they will be curious and want to know more about the flow of the plot. The author lets the readers figure out the plot of the story by themselves. To strengthen the readers' assumption, the clause is supported by another process too is shown in the following line: 
'there is someone in the world who is quite happy'

\begin{tabular}{llll}
\hline (There) is & someone & $\begin{array}{l}\text { in the } \\
\text { world }\end{array}$ & $\begin{array}{l}\text { who is } \\
\text { quite } \\
\text { happy }\end{array}$ \\
\hline Existential & Existent & $\begin{array}{l}\text { Circ: } \\
\text { location }\end{array}$ & $\begin{array}{l}\text { Mental: } \\
\text { affective }\end{array}$ \\
\hline & & Data no.15
\end{tabular}

The existential process concerned with any kinds of existent phenomena. Data number 15 shows the existence of a person; a character in the story, which comes to another character's mind that is the Happy Prince.

It is not always a character which is shown by the existential process but the situation as well. For instance:

'There is not a single cloud in the sky'

\begin{tabular}{llr}
\hline (there) is & $\begin{array}{l}\text { not a single } \\
\text { cloud }\end{array}$ & in the sky \\
\hline Existential & Existent & Circ.: location \\
\hline & & Data no.72
\end{tabular}

'Far away in a little street, there is a poor house'

\begin{tabular}{lll}
\hline $\begin{array}{l}\text { far away in a } \\
\text { little street }\end{array}$ & there is & $\begin{array}{l}\text { a poor } \\
\text { house }\end{array}$ \\
\hline Circ.: location & Existential & Existent \\
\hline & & Data no.112
\end{tabular}

By using the existential processes, Oscar Wilde illustrated the situation and the condition of the story so that the readers can understand the plot very well. Data number 72 describes the specific condition of the night and data number 112 describes the specific situation of the city.

In the story, Wilde frequently interweaves the existential process with relational process to give the detail information about the situation and the presented condition. Moreover, there was also another process to express the earth's atmosphere and its changes namely meteorological process which was conducted by Wilde. He used this process to express the weather condition presented in the story as the example below:

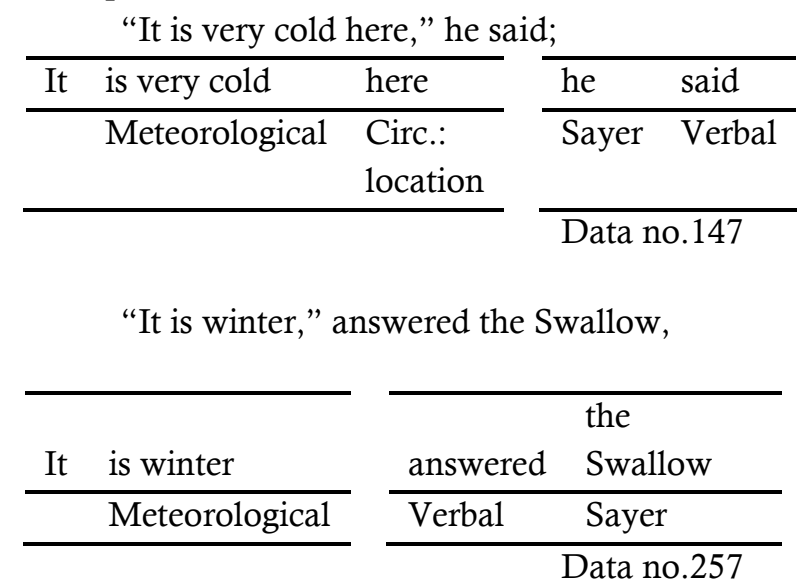

Based upon the explanation above, it proves that the types of processes used in the story have some influences on Oscar Wilde's writing style. He is an author who emphasizes the aesthetics of writing. Yet, he delivers the story with vivid description so that the readers can still easily interpret the sound, form of words, and the meaning in the text.

\section{Influences of Oscar Wilde's Previous Career and Achievements}

Oscar Wilde narrated the story of "The Happy Prince" with simple sentences and clear language. He mostly used simple sentences in the dialogue of the characters. Yet, in the narration he also used complex sentences to give additional information to the readers. Both in the dialogue and in the narration, he presented the clear language which was understandable even by the readers beyond the literary connoisseurs and the language observers. The following quotation shows one example of Wilde's simple dialogs:

Then the Swallow came back to the Prince. "You are blind now," he said, "so I will stay with you always." "No, little Swallow," said the poor Prince, "you must go away to Egypt." "I will stay with you always," said the Swallow, and he slept at the Prince's feet. ("The Happy Prince", 1888).

The use of simple and clear language shows that his writing was influenced by his previous career in journalism and editorship. 
Wilde worked as a journalist for a number of newspapers and magazines, including the daily evening paper Pall Mall Gazette, the weeklies Court and Society Review and the Speaker, and the monthly magazine Woman's World. He also penned essays for heavyweight periodicals such as the Fortnightly Review, the Nineteenth Century, and published fiction in Blackwood's Magazine and Lippincott's Monthly Magazine (Encyclopedia Britannica).

Best known for his conversational skill, Oscar Wilde presented the story in conversational style as the previous excerpt illustrated. At a glance, "The Happy Prince" tells about the sacrifice of a friendship, but it tells a deeper meaning, a deeper moral value to the readers. The story narrates a kind-hearted figure that represents the sincere concern of the author to the unfortunate poor people. Implicitly, the author also told about the inequity occurring in the society at that time, where the authority figure, in this case the Councilors, did not pay attention to the society especially the poor people around the city. They only focused on their benefits and their own life. This story was such a representation of a critic to the government in which the author wanted the government to eliminate the sufferings and liberate the poor people in the society. This is deeply influenced by Wilde's previous career, not only as a journalist but also a critic as well.

The explanation above shows that the author wrote the story not only to entertain the readers but also to inform them about what happened in the society around him. $\mathrm{He}$ implicitly gave the solution to solve the problem from his point of view. But still, he fabricated it in such a fanciful story. This indicates that Wilde is very concerned about the aesthetic of writing style. Aesthetic is a philosophical subject that deals with beauty, taste and art. In this style, the author has a freedom to twist the language in a manner that can create humor and eventually entertainment (Coakley, 1994)

\section{CONCLUSION}

By conducting Transitivity analysis, the context of situation is represented in the form of type of process found in the story. There are seven types of processes used in the story namely material process, mental process, behavioral process, verbal process, relational process, existential process, and meteorological process, which influenced Oscar Wilde's writing style especially in presenting vivid descriptions to his readers. He employs different processes to emphasize a different depiction so that is not only providing explicit content but also constructing aesthetic values. In developing the story, material process is the most frequently used process by the author. It indicates that he wants to point out the actions of the characters and the happenings around them. This might reflect the world of experiences of the author as we can see that his style of writing in portraying the entire story was also influenced by his early life including the previous career and achievement as a journalist, editor, and critic.

Furthermore, the researcher found that Oscar Wilde's writing style includes the vivid descriptions, aesthetic appearance, conversational style, repetitive pattern, simple and clear language.

\section{REFERENCES}

Beckson, Karl. (2018). Oscar Wilde Biography on Encyclopaedia Britannica. Available at https://www.britannica.com/biography/Osca r-Wilde [accessed 12/15/18]

Burns, Alvin C. and Ronald F. B. (2003). Marketing Research: Online Research Applications, 4th ed. London: Prentice Hall.

Cunanan, B.T. (2011). Using Transitivity as a Framework in a Stylistic Analysis of Virginia Woolf's Old Mrs. Grey. Asian EFL Journal. Professional Teaching Articles. Vol. 54.

Darani, Laya. (2014). Persuasive style and its realization through transitivity analysis: A SFL perspective. Procedia Social and Behavioral Sciences. 158. 179-186.

Dwi, W.S. (2010). Ideational Meaning and Thematic Analysis on Children's Songs in Barney "Dancing and Singing" Series. Tesis Universitas Diponegoro. 
Eggins, Suzanne. (1994). An Introduction to Systemic Functional Linguistics. London: Pinter Publishers Ltd.

Forster, E. M. 1985. Oxford Advanced Learner's Dictionary. Oxford: Oxford University Press.

Freeborn, Denis. (1996). Style: Text Analysis and Linguistic Criticism. London: Macmillan Press.

Gerot, L. and P. Wignell. (1994). Making Sense of Functional Grammar. Australia: Gerd Stabler.

Halliday, M. A. K. (1961). Categories of the theory of grammar. Word, 17(3), 242-92. http://dx.doi.org/10.1080/00437956.1961.11 659756

Halliday, M. A. K. (1963a). Class in relation to the axes of chain and choice in language. Linguistics, $\quad 2, \quad 5-15$. http://dx.doi.org/10.1515/ling.1963.1.2.5

Halliday, M. A. K. (1963b). Intonation in English grammar. Transactions of the Philological Society, 143-69. http://dx.doi.org/10.1111/j.1467968X.1963.tb01003.X

Halliday, M.A.K. and Christian Matthiessen. (2004). An Introduction to Functional Grammar Third Edition. London: Arnold.

Halliday, M. A. K. and R. Hasan. (1985). Language, Context, and Text. Melbourne: Deakin University.

Halliday, M. A. K. and R. Hasan. (1976).Cohesion in English. London: Routledge.

Kavalir, M. (2016). Paralysed: A Systemic Functional Analysis of James Joyce's Eveline. ELOPE: English Language Overseas Perspectives and Enquiries. Vol. 13 (2), 165-180(246).

Kerlinger, F.N. (1986). Foundations of Behavioral Research, 3rd ed. Fort Worth: Holt Rinehart \& Winston.

Library Research Process. Online at https://library.uaf.edu/ls101-research-process [accessed 18/09/27]

Litosseliti, L. (ed). (2010). Research Methods in Linguistics. Great Britain: MPG Books Group.

Mc Carthy, M. (1993). Discourse Analysis for Language Teachers. Cambridge: Cambridge University Press.

Mehmood, A. et al. (2014). European Journal of Research in Social Sciences, Transitivity Analysis: Representation Of Love In Wilde's The Nightingale and The Rose, 2, 4, 78-85.
Miles, Matthew B. \& A. Michael Huberman. 2014. Qualitative data analysis (3rd Ed). California: Sage publications Inc.

Moya, J. and M.J. Pinar. (2008). Compositional, Interpersonal and Representational Meanings in A Children's Narrrative. A Multimodal Discourse Analysis.Journal of Pragmatics. 40. 1601-1619.

Mujiyanto, Yan. (2011). Panduan Penulisan Skripsi. Semarang: Unnes Press.

Nguyen, H. T. (2012). International Journal of English Linguistics, Transitivity Analysis of "Heroic Mother" by Hoa Pham, 2, 4, 85-100.

Rasmuson. 2014. Library Research Process. Online at https://library.uaf.edu/1s101-research-process (2018/09/27)

Song, Z. (2013). Theory and Practice in Language Studies, Transitivity Analysis of A Rose for Emily, 3, 12, 2291-2295.

Webster, M. (1990). Websters Ninth New Collegiate Dictionary. USA: Merriam-Wesbter Inc.

Wilde, Oscar. (2007). The Happy Prince and Other Tales. New York: Random House USA Inc. 